\begin{tabular}{|c|c|}
\hline $\begin{array}{l}\text { ARTICLES } \\
\text { ARTICULOS }\end{array}$ & MANIPULATION, \\
\hline & PROFESSIONAL PRACTICES \\
\hline & AND DEONTOLOGY \\
\hline & IN INFORMATIONAL \\
\hline & PHOTOGRAPHY: \\
\hline $\begin{array}{r}\text { Copyright } \odot 2014 \\
\text { SBPjor / Associçacao } \\
\text { Brasileira de }\end{array}$ & identifying new parameters \\
\hline $\begin{array}{l}\text { Brassleria de } \\
\text { Pesquisadores em } \\
\text { Jornalismo }\end{array}$ & $\begin{array}{l}\mathrm{NHOZ} \\
\text { Federal da Bah }\end{array}$ \\
\hline
\end{tabular}

ABSTRACT - This paper investigates impacts of digital technologies on photographic postproduction and image manipulation in information photography. An attempt is made to assess the extent to which ethical codes and conventions are being modified concerning the digital treatment of photographic images. We sought to assess whether one can identify, in the rules of photographic competitions, an embryonic process of establishment of new boundaries as to what constitutes content manipulation and what is acceptable as technical adjustments. We observed that, in a large proportion of cases, competition rules consist of very generic guidelines regarding the acceptable procedures for photo editing, without clear distinctions between technical adjustment and manipulation. Despite such limitations, we conclude that the analysis of photographic competitions can lead to identification of observable regularities that may act as ethical standards in relation to post-production images.

Keywords: Contests photography. Image manipulation. Photography information. Deontology and ethics. Photojournalism.

\title{
MANIPULAÇÃO, PRÁTICA PROFISSIONAL E DEONTOLOGIA NA FOTOGRAFIA DE INFORMAÇÃO: identificando novos parâmetros
}

RESUMO - Este artigo investiga os impactos causados pelas novas tecnologias de edição digital sobre o campo da fotografia de informação. Busca-se avaliar em que medida os códigos e convenções deontológicas estão sendo alterados, em função das ferramentas de produção e tratamento digital da imagem fotográfica. Procurou-se avaliar se nas regras dos concursos de fotografia estariam sendo delimitadas fronteiras do que vem sendo visto como manipulação de conteúdo e do que caracterizaria apenas um ajuste técnico da imagem. Grande parte das normas analisadas, no que diz respeito aos procedimentos relativos à edição fotográfica, não define claramente a linha que separa o ajuste técnico da manipulação de conteúdo, ainda assim, as regras dos concursos podem levar à identificação de eventuais regularidades que funcionariam como parâmetros éticos em relação à pós-produção de imagens fotográficas.

Palavras-chave: Concursos de fotografia. Manipulação de imagens. Fotografia de informação. Deontologia e ética. Fotojornalismo.

\section{MANIPULACIÓN, PRÁCTICA PROFESIONAL Y DEONTOLOGÍA EN LA FOTOGRAFÍA DE INFORMACIÓN: identificando nuevos parámetros}

RESUMEN - Este trabajo investiga el impacto de las nuevas tecnologías de edición y manipulación digital en el campo de la fotografía de información. El objetivo es identificar indicadores de posibles cambios en los códigos y convenciones deontológicas, en función de la producción y procesamiento digital de la imagen fotográfica. Se pretende evaluar si en las normas de los concursos de fotografía se están determinando límites entre los ajustes técnicos aceptables de la imagen fotográfica y lo que viene siendo visto como manipulación de contenido. Los concursos han sido considerados indicadores válidos ya que son espacios institucionalizados de la práctica. Aunque gran parte de las normas analizadas presentan un carácter general en relación a los procedimientos para la edición de fotos $y$, a menudo, no se define claramente la línea entre la adaptación técnica y la manipulación, las reglas de las competiciones pueden permitir identificar regularidades que actúan como normas éticas en la posproducción de imágenes fotográficas. Palabras clave: Concursos de fotografía. Manipulación de imágenes. Fotografía de información. Deontología y ética. Fotoperiodismo. 


\section{INTRODUCTION}

As the history of photography shows us, "image manipulation", in a broad sense, is inherent to the process of producing photographic imagery (SOUSA, 1998; MITCHELL, 1992; WHEELER, 2002; LISTER, 1997; FONTCUBERTA, 1998). Choosing a specific angle, lens or depth of field can substantially alter how a particular scene is perceived. A scene can be manipulated by changing its context, thus encouraging a desirable interpretation. The post-production process - involving chemical treatments and controlled light exposure in the case of analog photography - has commonly been used to complete the process of intervention that would result in the "final image".

These image alteration possibilities certainly open up a range of discursive perspectives for photography. They turn subjectivity and image construction into the main virtues of visual language. However, the indiscriminate use of these alterations, especially by photography professionals, can undermine certainties, forcing us to be cautious and vigilant in relation to the images that surround us. We certainly cannot apply the same ethical rigidity regarding manipulation and the influencing of interpretation to all types of photography. According to Thomas Wheeler (2002), "the ethics of a photo, even a manipulated one, cannot be judged apart from its use". We must consider that photographic genres ${ }^{1}$ are in fact social constructs arising from the uses and meanings assigned to them. These values and meanings will, with the passing of time, be rejected or recovered in accordance with the personality, style or training of each practitioner (SOJO, 1998).

Since its earliest uses, informational photography - which aims to maintain maximum fidelity to the portrayed reality - has been evolving with an eye to the tension caused by manipulation-related choices and interventions. It has explored, in each era, the most appropriate ways to conform to the ethical regulatory landmarks of the current deontology (or ways to break them). During the analog period, some practices related to the technical construction of the photographic message were accepted without directly affecting the credibility of the information contained therein. Those practices included cropping, masks made in darkrooms and chromatic, contrast or brightness improvements. Specialists regarded these methods as image "treatment" rather than "manipulation" in the negative sense.

The emergence of digital photography has allowed for broad 
and democratic access to photography. The equipment has become affordable, intelligent and automated and the Web has created new opportunities. Very important possibilities are opened up by a myriad of new editing software programs that substantially increase the capacity to intervene in photography and greatly expand access to image treatment and manipulation techniques.

Easy to operate and highly intuitive, these programs provide inexperienced users with access to various possibilities for interfering with photo contents. This has exposed the multiple resources that can be used to interfere with the final look of photographs that are available to experts. Greater awareness of these resources has led to a gradual decrease of public faith in photographs (MOUTINHO, 2007; BAEZA, 2001; LONG, 1999), whose credibility and authenticity should be preserved.

Some types of interference, such as moving or removing objects or people from the registered framing, changing colors and adding elements, transfigure the notion of photography as the "mirror of reality". The observer is transported to a transformed world, a distorted and not always familiar reality, with illusions of existence (SOUZA, 1998; NEWTON, 2001; MOUTINHO \& SOUSA PINTO, 2007). In this article, we are concerned with the tools used in the postproduction stage, i.e., the technical procedures conducted after the photo was captured; from the photographic moment on.

With regard to post-production, the different levels of interference with the content of a photograph result in a dichotomy. Procedures can be divided in two groups:

a) Those aiming to falsify reality by manipulating and intervening directly in the content of the images, which we will call "manipulation";

b) Those in which the interferences are conducted through procedures that are considered to be indispensable, from a technical point of view, by many specialists and that supposedly do not change the meaning of what is shown. These interventions are usually called "image treatment". They represent an attempt to make the recorded image match the visible reality, compensating for technical limitations inherent to the equipment but preserving the integrity of the content (IRBY, 2003; SOUZA, 1998). Such procedures may involve subtle adjustments in color, luminosity or brightness; the reframing of the photograph; or the elimination of reflections, dust and other imperfections. 
This article is based on the premise that the line separating "manipulation" from the "acceptable treatment" of photographs (which aims to make only elementary adjustments) is becoming increasingly blurred because of the growing number of tools that can be used for interventions in the post-production stage. There is no consensus, even among experts, as to which procedures should be considered essential and/or ethically acceptable.

The limits of "acceptable treatment", which in analog photography somehow separated fiction from non-fiction and fake photos from those depicting the truth, have varied in different cultures and times. These limits have presently reached their point of maximum stretch.

This technologically generated tension demands that the specialists handling the information adopt a new approach when dealing with the frontier between what is permitted and what goes beyond the ethical standards of the deontology in their work (FRANQUET DOS SANTOS, 2011).

The following research questions were posed to guide this study. In the absence of prior consensus regarding what is and is not permitted in terms of digital intervention in photographic postproduction, where should the basic elements indicating a body of acceptable procedures be found? How much can a documental photograph be altered before it is considered to be of another type, such as artistic or fictional? When certain editing procedures are accepted, such as darkening, brightening, saturating or cropping an area of a photograph, what limits should be adopted to avoid a loss in the spirit or nature of the photograph?

Our focus in this paper is nonfiction photography, as defined by Wheeler: images with informational content employed in several types of media (i.e., the photojournalistic, documentary and scientific genres). It is within the domain of nonfiction photography that expectations of reality are built around registered facts and events. Therefore, in this category, the implications of authenticity and veracity are the most relevant, leading to the exacerbation of ethical and deontological aspects in relation to digital post-production. Thus, expectations of reality are built around facts and recorded events in the case of non-fictional photographs.

In the current framework of the consolidation and universalization of digital photography, we propose the following hypothesis to identify sources that generate deontological principles. 
Photographic contests - along with other institutions such as professional associations and media companies - constitute a good space to delineate "acceptable photographic treatment". In a preliminary effort, we specify some of the norms established in the main photography competitions devoted to the informational genres. Such contests do not permit manipulation in the content of images, or at least (as in photojournalism contests) should not permit it.

The domain of photography competitions is particularly relevant to this type of investigation because it develops institutions that aim to unite, with the aid of specialists in the field, the finest in their work. These events take place far from the restrictions of productive routine, in a context that allows for subjectivity. By analyzing the contest rules, it can be determined whether a delimitation of ethicaldeontological standards is emerging from these institutions of great legitimacy in the field.

The goal is to identify, within the rules made explicit by the competitions, regularities and recurrences that have been stipulated as ethical parameters in relation to interventions in the contents of photographic images during post-production.

The normative character that photograph contests assume with regard to technical procedures of intervention - is consolidated in the numerous cases of sanctions that have been applied to professional photographers for transgressing their standards, as reported by the media. Whether through a misunderstanding, bad faith on the part of the photographer or lack of clarity in the rules, such violations have led to embarrassment, ranging from disqualification - including the stripping of titles and awards - to public execration.

A transgression in the rules of a contest can even lead to exclusion from the professional field. An example of this is the case of Tracy Woodward, a photographer who was dismissed from the American newspaper The Washington Post. In 2013, he lost the "Eyes of History" prize, from the White House News Photographers Association, for having abused the Photoshop editing tool (fig. 01). What is curious in this case is that Woodward lost the prize due to a complaint from the very newspaper that he used to work for, after the company had accessed the original picture to publish news of the award. 
Figure 01 Photograph by Tracy Woodward, who was disqualified due to manipulation. The original is on the right ${ }^{2}$
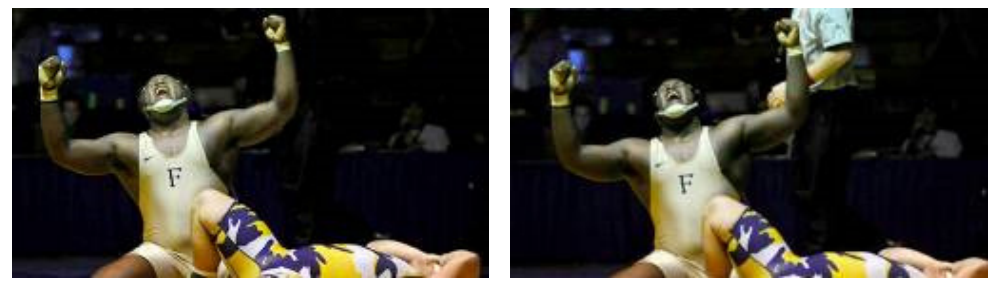

The assumption that contests should have a normative character, as institutions of the journalistic field, is part of another assumption: given the current technological possibilities, with regard to establishing new ethical standards, agonistic behavior is always present. The arguments to defend the professionals involved in relation to the pleas of the judges in competitions, may diverge greatly. Some of them have caused serious controversies in this domain. Although most photographers are conscious of the existence of a zone of tolerance, which distinguishes photographic treatment from manipulation or adulteration, this limit is not very clear.

In 2002, The Charlotte Observer, in a photography contest sponsored by the North Carolina Press Photographers Association, revoked three awards given to the photographer Patrick Schneider. The competition's judges reasoned that the editorial content of the photos had been altered through the darkening of parts of the pictures (fig. 02). The main argument in Schneider's defense was that, back in the days of the darkroom, photographers were allowed to extensively brighten or burn their photos without countering any ethical issues. According to Schneider, the rules of the competition were not clear in this regard ${ }^{3}$. This disqualification has motivated Pedro Meyer, a distinguished specialist in the field, to write a manifesto entitled "In defense of photographer Patrick Schneider: and the fictions of a 'Code of Ethics'”.

Figure 2 One of the disqualified photographs by Patrick Schneider. In the picture on the right, the background has been completely darkened ${ }^{4}$
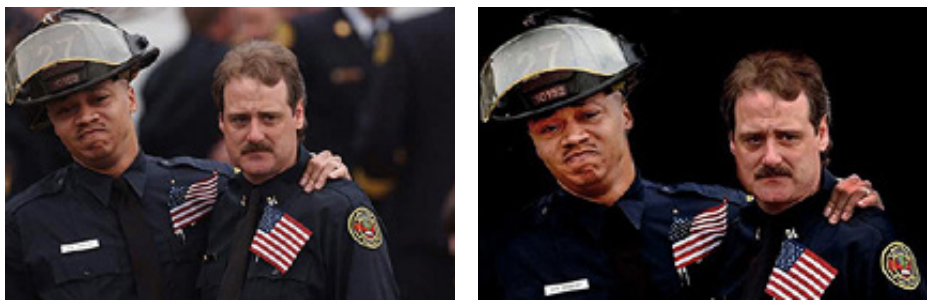
In 2012, Harry Fisch lost the award granted by the National Geographic Photo Contest, for having erased a plastic bag that was almost imperceptible in the picture (fig. 03). Noteworthy in this case was the declaration of Monica Corcoran, editor of the National Geographic. She said that the photographer could have either cropped the photo or darkened that area to make the bag almost invisible; however, the only thing he was not allowed to do was remove the object digitally. Although, according to the photographer, the subtlety of the manipulation did not alter the substance of the picture, he violated a basic contest rule and was irrevocably punished.

Figure 3 Photograph by Harry Fisch, disqualified 72 hours after winning the National Geographic competition because he removed a plastic bag from the original photo (on the right) ${ }^{5}$
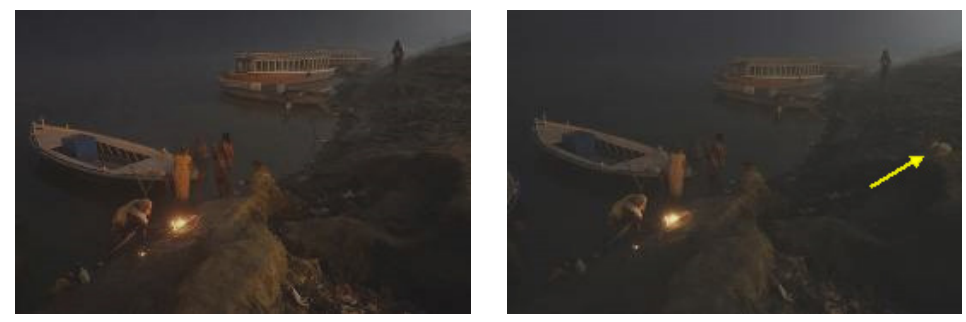

Numerous other cases of disqualification or withdrawal of rewards have occurred (some more questionable than others), based on flagrant or at least alleged manipulation. David Byrne had to return the prize for "Landscape Photographer of the Year" from the National Theatre, in London, England. He was exposed on the Internet and lost the first place for having edited his photo, entitled "Lindisfarne Boats" . He was too extreme in using Photoshop to transform his image, which was not permitted by the rules of the competition. The case of Stepan Rudik, in 2010, was also quite controversial. He was disqualified from one of the main professional photography contests, the World Press Photo (WPP), for having removed the tip of a shoe that was virtually undetectable in the photograph. In Rudik's picture, which shows a hand being bandaged, it was considered acceptable for him to crop, include a vignette and considerably desaturate the image, but it was not acceptable to remove a small background element in a picture that had already been cropped and desaturated (fig. 04). 
Figure 4 The photograph by Stepan Rudik (third from right) submitted to the WPP contest and disqualified for manipulation?
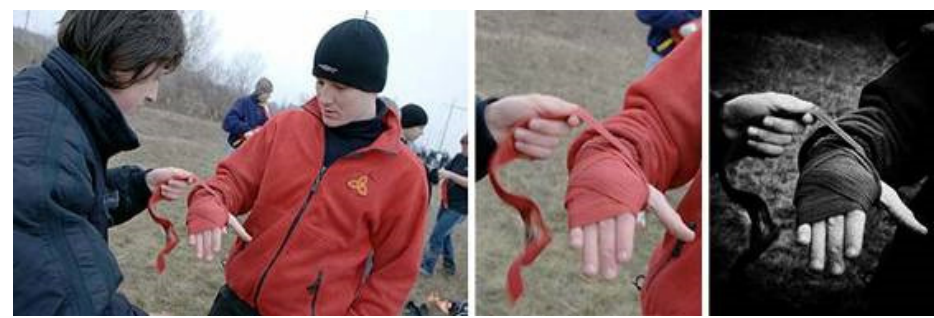

The two previously mentioned assumptions indicate that the search for definitive rules among contests will lead us to something even more important. This analysis will help us to reveal a possible consensus-building trend and could illuminate areas of sharp dissent in the photography arena.

\section{METHODOLOGY}

In terms of methodology, we collected data by observing the rules of major informational photography competitions (journalistic, scientific, documentary, environmental, wildlife, etc.). We used an observation grid to measure the photographic editing elements that should be emphasized. This allowed us to analyze the contest rules in a homogeneous way, ensuring greater objectivity towards the collected data.

The investigation was systematically conducted over six months. During this period, the rules of Brazilian and international photography contests were analyzed. The regulations, usually available on the Internet, were collected between 2011 and 2013. The goal was to study competitions that, due to the chosen types of photographs or themes, did not permit any image treatment, or at least aimed for the content and authenticity of the images to be preserved to the greatest possible degree.

The observations consist of contests that are simultaneously directed toward professionals and amateurs. Among the chosen types and themes, we highlight the following: documentary, scientific, photojournalistic, reportage, humanitarian-oriented and those focused on astronomy, nature, wildlife, environment, people and cities. 
In our search, we examined competition and other relevant websites, such as those of the Photography Competitions Network $^{8}$ (PCN) and "Photography in Portuguese"9 (Fotografia em Língua Portuguesa - FLINPO), which indicate photography contests in various parts of the world. We also searched the hashtags \#concursofotografia and \#photocontest on Twitter and Google.

Our procedure was to identify competitions with one of our themes of interest and, based on its rules, verify what its objectives were and who was allowed to compete. Next we would identify its specifications and restrictions regarding photographic editing. All this information was finally organized in tables, which will be examined later in this article.

A total of 66 national and international competitions was compiled as the universe for study and the first observation was that $42 \%$ of them provided no specific instructions or restrictions directly relating to photographic post-production, apart from very generic prohibition phrases, such as "The photos cannot be digitally manipulated" ("As fotos não poderão ser manipuladas digitalmente")10, "the photo should not be subject to montage, correction or computational instrumentation" (“a fotografia não poderá ser objeto de qualquer tipo de montagem, retoque ou recurso instrumental de computação") 1", "subtractions or additions of elements to the original photographic image will not be acceptable" "no se aceptan fotografías con modificaciones, donde se inserten o sustraigan elementos de la imagen original")12; or else the only disposition was a declaration, signed by the competitor, that "the photos I am entering are neither photomontage nor have been manipulated or digitally altered in their essence (sic)"13 or something to that effect.

Within the universe of competitions analyzed, some of them do not present a single line of orientation as to admissible post-production treatment or clear indications of what would constitute inadmissible manipulation. Competitions of considerable importance such as Prêmio Latino Americano de Fotografía, The Alexia Foundation, Magnun Expression Award, Nikon Small World Photomicrography Competition, Astronomy Photographer of The Year 2013, were examples of a total lack of explicit orientation to competitors.

In order to renderclearer the imposed delimitations, flexibilities and formal rigors as to acceptable post-production treatments in the competitions' rules, we created two grids for classification with their 
resulting tables, concerning the various aspects of photographic treatment. In a first type of table (Tables 1a, 1b, 1c, 1d 1e) we indicate the normative positions of each competition concerning specific alterations, such as tonal curve, saturation, contrast, focus etc, thus producing a mapping of permissions and prohibitions or "no mentions" for each one of items in all competitions included in the universe of research. Those competitions characterized by "generic rules" were placed in a separate table (Table 2 ), as it was impossible to determine - via such vague rules - what was actually admissible as "photographic treatment of the image" and what was to be considered "manipulation", thus invalidating the entry.

\section{TABLE 1 - ANALYZING SPECIFIC TECHNIQUES: PERMITTED, PROHIBITED AND OMITTED ELEMENTS}

To build up this series of tables, the major interventions that can be carried out in post-production through photo editing software were recognized and listed. It is worth noting that many of the editing techniques (treatment and manipulation) listed here have been employed since the days of film photography and darkrooms. Some of them are more sophisticated and required deeper knowledge and skills on the part of the operator, whereas others used to be carried out routinely.

Among the written rules of the examined competitions, we then identified the techniques considered acceptable. We designated these tools with the letter "Y". For those techniques that were clearly prohibited by the rules, we used the letter "N", and for those that were not mentioned, we used the symbol "-". In this way, after identifying each competition with an abbreviation ${ }^{14}$, we continued to investigate their norms item by item, identifying whether every major photoediting technique was permitted, prohibited or omitted.

We list below the major editing techniques, explaining their main features ${ }^{15}$ :

- Cropping - removal of the edges of an image. Usually used to frame it within a newspaper page or to create the desired impact.

- Brightness - adjustment of tones; it refers to the brilliance of an image. 
- Contrast - adjustment of the range between the light and dark tones in the image.

- Removing/adding - the addition or removal of elements to a photograph after it was registered, either by cloning or through another technique.

- Sharpening -increasing the sharpness/focus of an image.

- $\quad \mathbf{B} \& \mathbf{W}$ (black and white) - a photograph that has only shades of gray, black and white. This effect can be programmed into the camera or achieved via software.

- Saturation -enhancement of various or single colors in images.

- Curves -a feature that defines the relationship between the inputs and outputs of the tonal range of the image. It is used to adjust tonal ranges, change color levels and exposures and improve contrast.

- Color setting - in our table, this term refers to the natural adjustment of color, taking into account the color range in which the picture was produced and the adequacy of the white balance.

- Desaturation - the conversion of a color photograph into a monochromatic one.

- Dodging - brightening of an area in the image.

- Burning - darkening of an area in the image.

- Reframing - process of repositioning the main subject of the photo in frame through adjustments in the inclination and edges.

- Cloning - tool used to copy certain areas of the photo and put them in another part of the image or eliminate undesired content.

- $\quad$ HDR (high dynamic range) - the idea of HDR imaging is to capture a greater dynamic range between the lightest and darkest areas of an image. HDR images can more accurately represent the range of intensity levels found in real scenes than standard digital imaging.

- Double/multiple exposure - the exposure of the same photogram two or more times. This term can also refer to a series of pictures based on a fixed framing. 
- Masks - allows for the isolation or protection of certain areas of an image and the addition of effects such as filters, color changes, etc., to the other areas of the same image.

- Digital filtering - the application of algorithms to images to obtain certain effects, such as posterization, sharpening, etc.

- RAW file - a file with all of the original image information as captured by the camera sensor, before any processing.

Table $1 . a$

\begin{tabular}{|c|c|c|c|c|c|c|c|c|c|}
\hline $\begin{array}{l}\text { CONTESTS } \\
\text { ALTERATIONS }\end{array}$ & $\begin{array}{l}\text { NPPA } \\
\text { BOP }\end{array}$ & $\begin{array}{l}\text { POYi } \\
\text { LAm. }\end{array}$ & Pulitzer & $\begin{array}{l}\text { Dayeux- } \\
\text { cahrados }\end{array}$ & POTY & $\begin{array}{l}\text { Net } \\
\text { Ges }\end{array}$ & $\begin{array}{l}\text { Smichso- } \\
\text { nian }\end{array}$ & $\begin{array}{l}\text { Slane } \\
\text { the } \\
\text { VEw }\end{array}$ & PPY \\
\hline Cropsing & $\mathbf{Y}$ & - & $\mathbf{Y}$ & $\mathbf{Y}$ & $\mathbf{Y}$ & $\mathbf{Y}$ & $Y$ & Y & $\mathrm{N}$ \\
\hline Briglutness & - & - & - & - & - & $\mathbf{Y}$ & - & $\mathbf{Y}$ & - \\
\hline Contrast & $\mathbf{Y}$ & - & - & - & - & $\mathbf{Y}$ & $\mathbf{Y}$ & $\mathbf{Y}$ & - \\
\hline Removing/adding & $\mathbf{N}$ & - & - & - & $\mathbf{N}$ & $\mathbf{N}$ & $\mathbf{N}$ & $\mathbf{N}$ & $\mathbf{N}$ \\
\hline Sharpeaing & - & - & - & - & - & $\mathbf{Y}$ & $Y$ & $\mathbf{Y}$ & - \\
\hline BEW & - & - & $\mathbf{Y}$ & $\mathbf{Y}$ & - & $\mathbf{Y}$ & - & - & $\mathbf{Y}$ \\
\hline Saturatioa - colos & - & $\mathbf{N}$ & - & - & $\mathrm{N}$ & $\mathbf{N}$ & - & $\mathbf{Y}$ & $\mathbf{N}$ \\
\hline Curves & - & - & - & - & - & $\mathbf{Y}$ & - & $\mathbf{Y}$ & - \\
\hline Color & $\mathbf{Y}$ & $\mathbf{Y}$ & - & - & - & $\mathbf{Y}$ & $\mathbf{Y}$ & $\mathbf{Y}$ & - \\
\hline Desaturation & - & - & - & - & $\mathbf{Y}$ & $\mathbf{N}$ & - & - & - \\
\hline Dodging & $\mathbf{Y}$ & - & - & - & - & $\mathbf{Y}$ & $Y$ & - & - \\
\hline Buming & $\mathbf{Y}$ & - & - & - & - & $\mathbf{Y}$ & $\mathbf{Y}$ & - & - \\
\hline Reframing & - & - & - & - & - & $\mathbf{Y}$ & - & - & $\mathbf{N}$ \\
\hline Cloning & - & $\mathbf{N}$ & - & - & $\mathbf{N}$ & $\mathbf{N}$ & $\mathbf{N}$ & $\mathbf{N}$ & $\mathbf{N}$ \\
\hline HDR & - & $\mathrm{N}$ & - & - & $\mathrm{N}$ & $\mathbf{N}$ & - & $\mathbf{Y}$ & - \\
\hline Moultiple exposure & - & $\mathbf{N}$ & - & - & - & - & - & - & $\mathbf{N}$ \\
\hline Mask & - & $\mathrm{N}$ & - & - & $\mathrm{N}$ & - & $\mathbf{N}$ & - & - \\
\hline Digiral flitrering & - & $\mathbf{N}$ & - & - & $\mathbf{N}$ & $\mathbf{N}$ & $\mathbf{N}$ & $\mathbf{N}$ & - \\
\hline RAW files & - & - & - & - & - & $\mathbf{Y}$ & $Y$ & $\mathbf{Y}$ & $\mathbf{Y}$ \\
\hline
\end{tabular}

\section{Caption:}

$\mathbf{Y}$ - Allowed

$\mathbf{N}$ - Not allowed

- Not mentioned 
Table 1.b

\begin{tabular}{|c|c|c|c|c|c|c|c|c|c|}
\hline $\begin{array}{l}\text { CONTEST/ } \\
\text { ALTERATIONS }\end{array}$ & HPA & Atlanta & YIPPA & Hearst & $\begin{array}{l}\text { DAYS } \\
\text { JAPAN }\end{array}$ & $\begin{array}{l}\text { FIFTH } \\
\text { ANNU }\end{array}$ & BELAR & OASIS & WPP \\
\hline Cropping & - & $\mathbf{Y}$ & $\mathbf{Y}$ & $\mathbf{Y}$ & $\mathbf{Y}$ & - & $\mathbf{Y}$ & $\mathbf{Y}$ & - \\
\hline Brightness & - & - & - & - & - & $\mathbf{Y}$ & - & $\mathbf{Y}$ & - \\
\hline Contrast & - & - & - & $\mathbf{Y}$ & - & - & $\mathbf{Y}$ & $\mathbf{Y}$ & - \\
\hline Removing/adding & $\mathbf{N}$ & $\mathbf{N}$ & $\mathbf{N}$ & $\mathrm{N}$ & $\mathbf{N}$ & - & $\mathbf{N}$ & $\mathbf{N}$ & - \\
\hline Sharpening & - & - & $\mathbf{Y}$ & - & _- & _- & - & $\mathbf{Y}$ & _ \\
\hline$B \& W$ & - & - & $\mathbf{Y}$ & - & $\mathbf{Y}$ & _ & - & $\mathbf{Y}$ & $\mathbf{Y}$ \\
\hline Saturation - color & $\mathbf{N}$ & - & $\mathrm{N}$ & $\mathrm{N}$ & - & - & - & $\mathrm{N}$ & - \\
\hline Curves & - & - & - & - & - & - & - & - & - \\
\hline Color & - & $\mathbf{Y}$ & - & $\mathbf{Y}$ & - & - & - & $\mathbf{Y}$ & - \\
\hline Desaturation & - & - & - & - & - & - & - & - & - \\
\hline Dodging & - & $\mathbf{Y}$ & $\mathbf{Y}$ & - & $\mathbf{Y}$ & - & - & - & - \\
\hline Buming & - & $\mathbf{Y}$ & $\mathbf{Y}$ & - & $\mathbf{Y}$ & - & - & - & - \\
\hline Reframing & - & - & - & - & $\mathrm{N}$ & - & - & - & - \\
\hline Cloning & $\mathrm{N}$ & - & $\mathrm{N}$ & $\mathrm{N}$ & - & - & - & $\mathrm{N}$ & $\mathrm{N}$ \\
\hline HDR & - & - & - & - & - & - & - & - & - \\
\hline Multiple exposure & - & - & $\mathrm{N}$ & $\mathbf{N}$ & - & - & $\mathbf{N}$ & $\mathbf{N}$ & $\mathbf{N}$ \\
\hline Mask & $\mathrm{N}$ & - & $\mathrm{N}$ & $\mathrm{N}$ & - & - & - & $\mathrm{N}$ & - \\
\hline Digital filtering & $\mathrm{N}$ & - & $\mathrm{N}$ & - & - & - & - & $\mathrm{N}$ & $\mathrm{N}$ \\
\hline RAW files & - & - & $\mathbf{Y}$ & - & - & - & $\mathbf{Y}$ & $\mathbf{Y}$ & Y \\
\hline
\end{tabular}

Table 1.c

\begin{tabular}{|c|c|c|c|c|c|c|c|c|c|}
\hline $\begin{array}{l}\text { CONTEST/ } \\
\text { ALTERATIONS }\end{array}$ & MPP & $\begin{array}{l}\text { NORTH } \\
\text { EAST }\end{array}$ & WILDLIFE & METEO & \begin{tabular}{|l|} 
POY \\
LATAM
\end{tabular} & BWPA & $\begin{array}{l}\text { DEFPN } \\
\text { DERS }\end{array}$ & IKPA & KL \\
\hline Cropping & $\mathbf{Y}$ & $\mathbf{Y}$ & $\mathbf{Y}$ & $\mathbf{Y}$ & $\mathbf{Y}$ & $\mathbf{Y}$ & $\mathbf{Y}$ & $\mathbf{Y}$ & $\mathbf{Y}$ \\
\hline Brightness & - & - & $\mathbf{Y}$ & $\mathbf{Y}$ & - & $\mathbf{Y}$ & _ & - & - \\
\hline Contrast & $\mathbf{Y}$ & $\mathbf{Y}$ & $\mathbf{Y}$ & $\mathbf{Y}$ & - & $\mathbf{Y}$ & $\mathbf{Y}$ & - & - \\
\hline Removing/adding & $\mathrm{N}$ & $\mathbf{N}$ & $\mathrm{N}$ & $\mathrm{N}$ & $\mathbf{N}$ & $\mathrm{N}$ & $\mathrm{N}$ & $\mathbf{N}$ & - \\
\hline Sharpening & - & $\mathbf{Y}$ & $\mathbf{Y}$ & - & - & $\mathbf{Y}$ & - & - & $\mathbf{Y}$ \\
\hline B\&W & $\mathbf{Y}$ & $\mathbf{Y}$ & $\mathbf{Y}$ & $\mathbf{Y}$ & $\mathbf{Y}$ & $\mathbf{Y}$ & - & - & $\mathbf{Y}$ \\
\hline Saturation - color & - & $\mathbf{N}$ & $\mathbf{Y}$ & - & $\mathrm{N}$ & $\mathbf{Y}$ & - & - & - \\
\hline Curves & - & $\mathbf{N}$ & $\mathbf{Y}$ & - & $\mathbf{Y}$ & $\mathbf{Y}$ & - & - & $\mathbf{Y}$ \\
\hline Color & $\mathbf{Y}$ & $\mathbf{Y}$ & $\mathbf{Y}$ & - & _ & $\mathbf{Y}$ & $\mathbf{Y}$ & $\mathbf{Y}$ & $\mathbf{Y}$ \\
\hline Desaturation & - & - & - & - & $\mathbf{N}$ & $\mathbf{Y}$ & - & - & - \\
\hline Dodging & - & $\mathbf{Y}$ & $\mathbf{Y}$ & $\mathbf{Y}$ & - & $\mathbf{Y}$ & - & - & $\mathbf{Y}$ \\
\hline Burning & - & $\mathbf{Y}$ & $\mathbf{Y}$ & $\mathbf{Y}$ & - & $\mathbf{Y}$ & - & - & $\mathbf{Y}$ \\
\hline Reframing & - & - & - & - & - & - & - & - & - \\
\hline Cloning & - & $\mathbf{N}$ & - & - & - & $\mathbf{N}$ & $\mathbf{N}$ & - & $\mathbf{N}$ \\
\hline HDR & - & - & - & - & - & - & - & - & $\mathbf{N}$ \\
\hline Multiple exposure & $\mathbf{N}$ & - & $\mathbf{Y}$ & $\mathbf{N}$ & $\mathbf{N}$ & $\mathbf{Y}$ & _ & - & - \\
\hline Mask & - & - & $\mathbf{N}$ & $\mathbf{N}$ & $\mathbf{N}$ & - & - & - & $\mathbf{N}$ \\
\hline Digital filtering & - & - & $\mathbf{Y}$ & - & $\mathrm{N}$ & - & - & - & - \\
\hline RAW files & - & $\mathbf{Y}$ & $\mathbf{Y}$ & $\mathbf{Y}$ & - & $\mathbf{Y}$ & - & - & $\mathbf{Y}$ \\
\hline
\end{tabular}


Table 1.d

\begin{tabular}{|c|c|c|c|c|c|c|c|c|c|}
\hline $\begin{array}{l}\text { CONTEST/ } \\
\text { ALTERATIONS }\end{array}$ & MORA & $\begin{array}{l}\text { EURO } \\
\text { NATUR }\end{array}$ & $\begin{array}{l}\text { WALK } \\
\text { LEY }\end{array}$ & $\begin{array}{l}\text { MEL } \\
\text { VITA }\end{array}$ & NATURAL & NATURE & EOLO & MASKE & SHOOT \\
\hline Cropping & - & $Y$ & $\mathbf{Y}$ & $\mathbf{Y}$ & $\mathbf{Y}$ & $\mathbf{Y}$ & - & $\mathbf{Y}$ & $\mathbf{Y}$ \\
\hline Brightness & - & $\mathbf{Y}$ & - & - & $\mathbf{Y}$ & - & $\mathbf{Y}$ & - & $\mathbf{Y}$ \\
\hline Contrast & $\mathbf{Y}$ & $\mathbf{Y}$ & - & $\mathbf{Y}$ & $\mathbf{Y}$ & $\mathbf{Y}$ & $\mathbf{Y}$ & - & $\mathbf{Y}$ \\
\hline Removing/adding & $\mathrm{N}$ & $\mathrm{N}$ & - & $\mathrm{N}$ & - & $\mathrm{N}$ & $\mathbf{N}$ & - & $\mathrm{N}$ \\
\hline Sharpening & - & - & - & $\mathbf{Y}$ & $\mathbf{Y}$ & - & - & - & $\mathbf{Y}$ \\
\hline$B \& W$ & $\mathbf{Y}$ & $\mathbf{Y}$ & - & $\mathbf{N}$ & - & - & - & $\mathbf{Y}$ & $\mathbf{Y}$ \\
\hline Saturation - color & - & $\mathrm{Y}$ & - & $\mathrm{N}$ & $\mathbf{Y}$ & - & - & - & - \\
\hline Curves & - & $\mathbf{Y}$ & - & $\mathbf{Y}$ & $\mathbf{Y}$ & - & - & - & - \\
\hline Color & $\mathbf{Y}$ & $\mathbf{Y}$ & - & $\mathbf{Y}$ & $\mathbf{Y}$ & $\mathbf{Y}$ & $\mathbf{Y}$ & $\mathbf{Y}$ & $\mathbf{Y}$ \\
\hline Desaturation & - & - & - & - & - & - & - & - & - \\
\hline Dodging & - & - & $\mathbf{Y}$ & - & $\mathbf{Y}$ & - & - & - & - \\
\hline Burning & - & - & $\mathbf{Y}$ & - & $\mathbf{Y}$ & - & - & - & - \\
\hline Reframing & $\mathbf{Y}$ & - & - & - & - & - & - & $\mathbf{Y}$ & $\mathbf{Y}$ \\
\hline Cloning & - & $\mathbf{N}$ & $\mathbf{N}$ & - & - & - & - & - & - \\
\hline HDR & - & $\mathrm{N}$ & - & $\mathbf{Y}$ & - & - & - & - & - \\
\hline Multiple exposure & - & $\mathbf{Y}$ & - & $\mathbf{Y}$ & $\mathbf{Y}$ & - & - & - & - \\
\hline Mask & - & - & $\mathbf{N}$ & - & - & - & $\mathbf{N}$ & - & - \\
\hline Digital filtering & - & - & - & $\mathbf{N}$ & - & - & - & - & - \\
\hline RAW files & $\mathbf{Y}$ & $\mathbf{Y}$ & - & $\mathbf{Y}$ & $\mathbf{Y}$ & $\mathbf{Y}$ & - & - & $\mathbf{Y}$ \\
\hline
\end{tabular}

Table 1.e

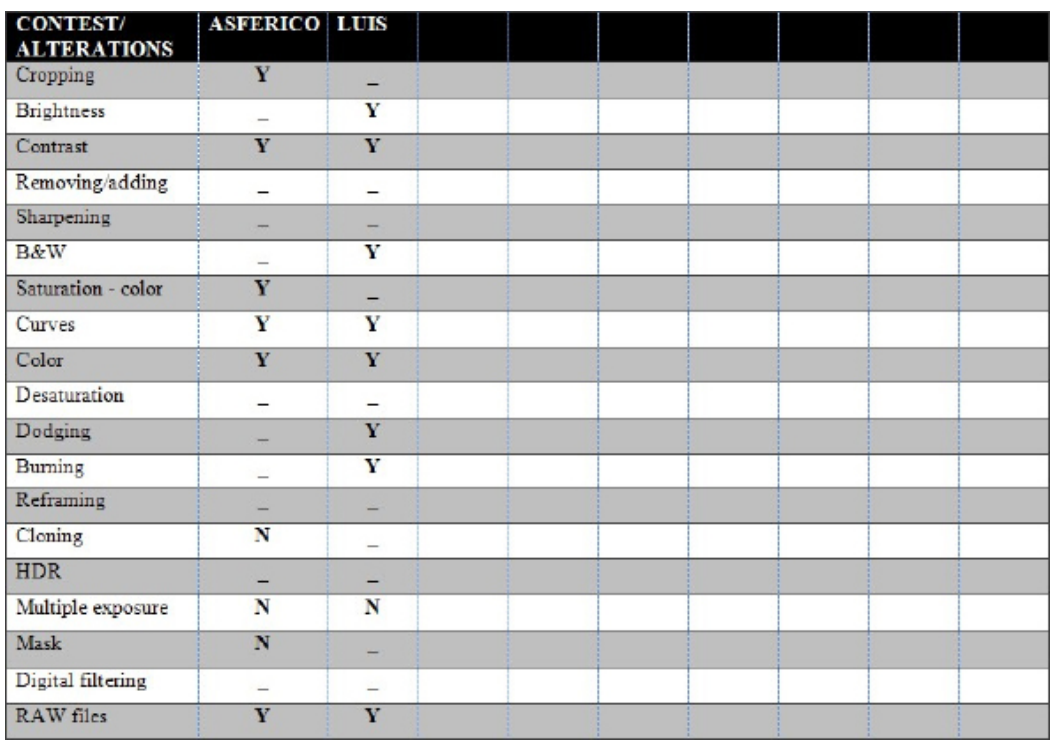




\section{DATA ANALYSIS}

In this part of the paper, we will examine the data included in Tables 1.a, 1.b, 1.c, 1.d and 1.e. To elaborate these tables, we only took into account the data collected in those contests that textually indicate whether the use of certain specific editing techniques is permitted (in the caption: "allowed" and "not allowed"). We included the item "not mentioned" in the caption to refer to those techniques cited in the rules of some contests but absent in those of others. Furthermore, we created Table 2 to include those competitions that are very imprecise in their rules with regard to manipulation and do not mention any particular techniques, not even those specified in Table 1. We listed such competitions in a different table to avoid distorting the results of the survey.

In the following graph (fig. 05) the result of our analysis is expressed in percentages to allow for a better visualization of the data obtained from Table 1:

\section{Figure 5}

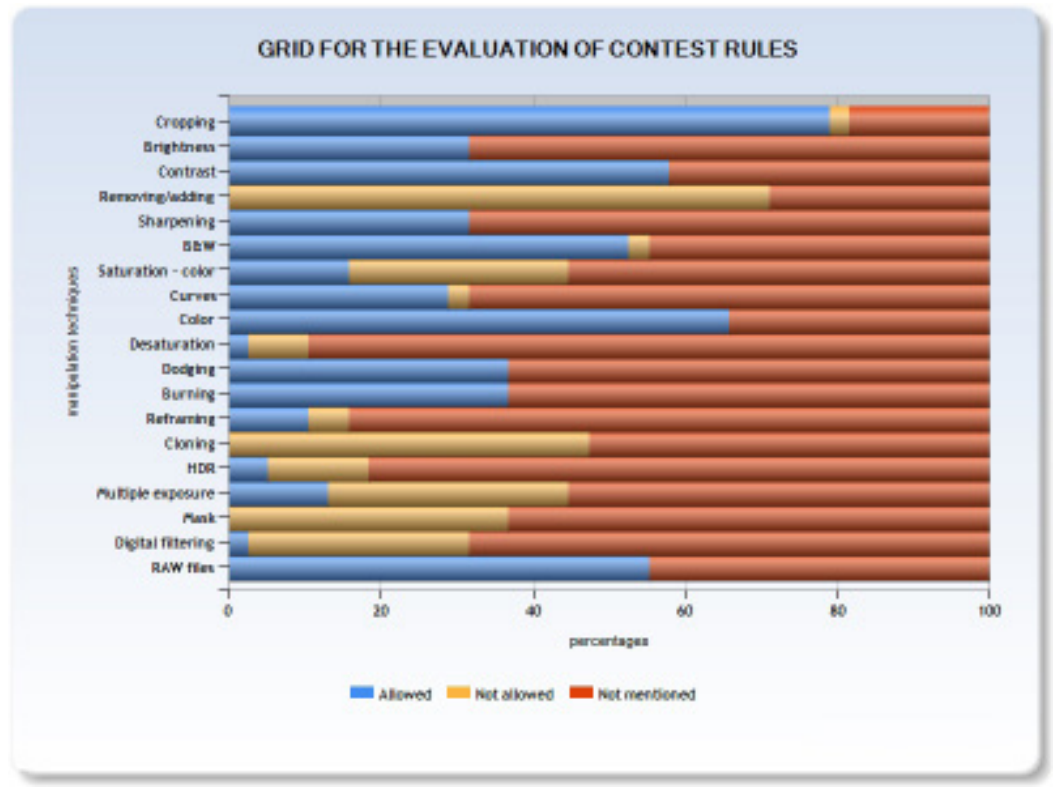

The predominance of the color red ("not mentioned") on the graph indicates a strong tendency to omit certain techniques, which we consider fundamental for the clarity of the ethical landmarks of 
the contests. This occurs even among those contests that indicate the validity of at least one procedure. The items "sharpness" (which can greatly transform a photograph), and "reframing" (which is not mentioned by $89 \%$ of competitions) are good examples of techniques that are often ignored by the contests despite being frequently evaluated within the debate about the limits of photo editing.

We notice that only a few regulations analyze these procedures in detail, delimiting the level of permitted altering. Among them we highlight the rules of the National Geographic Photo Contest; the Wildlife Photographer of the Year; and the British Wildlife Photography Awards (BWPA) which, according to Tables 1a and 1c, make allusions to nearly all of the 19 items in our table.

The chart also indicates a tendency to allow the use of minor adjustments and only a few techniques, although the vast majority of these contests do not specify the levels of transformation permitted. The lack of clarity in these limits has caused many controversies. If it is permitted, for example, to darken a specific area of a picture (burning), why is it prohibited to burn it until it is completely occluded when the alteration limit is not made explicit?

Of the allowed techniques, we highlight cropping (79\%), B\&W (52\%), changes in contrast (58\%) and color (58\%). To this list, we can also add burning, dodging and adjustments in sharpness and brightness, which were permitted in an average of $35 \%$ of competitions and were not banned in any instances. It is also interesting to call attention to the requirement that photographers present the RAW file, if prompted by the judges. The RAW file enables the judges to check any change made in the photo. Of all of the analyzed competitions, 55\% warn (or threaten?) the competitors that the presentation of the original photo file might be required and that they will be disqualified if they fail to present it.

In addition, we identified a consensus in the strict prohibition of certain techniques, some of which are directly linked to digital editing, as in the case of cloning. This procedure is prohibited in $47 \%$ of the contests, although in the other $53 \%$ there is no mention of it in the rules. This is remarkable considering that this technique has been responsible for many of the ethical dilemmas, constantly denounced by the media, which have generated disqualifications and even the dismissal of professional photographers from their jobs. This applies to the previously mentioned example of Harry Fisch, who, in a matter 
of 72 hours, lost his title as the winner of one of the most important photo contests and was publicly execrated.

Other procedures are clearly delineated as forbidden. In addition to cloning, we highlight removing/adding (71\%), masks (37\%) (in these cases, there are no remarks about concessions), digital filtering (29\%) and double/multiple exposure (32\%). Few contests (3\%) tolerate digital filtering without clearly specifying which filters are used and double/multiple exposures (13\%); these cases closely correspond to the $5 \%$ that also permit photographs captured in high dynamic range (HDR), according to the technological requirements of this tool.

$\mathrm{HDR}^{16}$ is a relatively new method from the digital era. For some, this technology, which offers a greater dynamic range of tones and details, does not change the authenticity of the scene or situation. However, others feel that HDR is just another digital manipulation. The controversy around this technique was intensified when The Washington Post published an HDR photograph by Bill O'Leary on its front page ${ }^{17}$. This provoked innumerous debates about the acceptability of this intervention in informational photography. This debate is far from finished, given that some strict contests accept HDR while simultaneously prohibiting manipulations in their rules.

\section{TABLE 2 - SELECTING CERTAIN NORMATIVE OBSERVATIONS}

Table 2 was elaborated to underline some comments found in the rules of the selected competitions regarding photo editing. We included some contests that make general observations but do not specify, clearly and unambiguously, which techniques are tolerated and which are forbidden when editing photos to be submitted. Therefore, these competitions do not appear in previous tables.

In Table 2, other ambiguous remarks are also highlighted. With all this information, we should be able to analyze whether these comments contribute to elucidating the limits of photo editing for professional photographers. If this is the case, such comments could be used as a guide in the search for ethical principles. 
Table 2

\begin{tabular}{|c|c|}
\hline NPPA BOP & $\begin{array}{l}\text { Editing should maintain the integrity of the photographic images' content and context. Do not manipulate } \\
\text { images in any way that can mislead viewers or misrepresent subjects. }\end{array}$ \\
\hline POYi & Images in anv way rnat can mislead viewers or misrepresent subjects. \\
\hline PUULITZ & No photographs may be manipulated or altered, apart from standard cropping or editing. \\
\hline $\begin{array}{l}\text { BAYEUX } \\
\text { POTY }\end{array}$ & $\begin{array}{l}\text { Photo report must preserve the authenticity of the image } \\
\text {...minor digital enhancement for cropping, red-eye removal, filters, and corrective functions are permitted. }\end{array}$ \\
\hline & Images MUST maintain the integrity of the scene as it was photographed. \\
\hline NATGEO & Any changes to the original Photograph not itemized here are \\
\hline SMITHSO- & $\begin{array}{l}\text { or alter your photographs (beyond the basics needed to achieve realistic color balance and sharpness) } \\
\text { Minor adjustments, including spotting, dodging and burning, sharpening, contrast and slight color adjustment }\end{array}$ \\
\hline & or the digital equivalents, are acceptable. \\
\hline SHARE THE VIEW & $\begin{array}{l}\text { Basic processing including, but not limited to, color correction, exposure adjustment, spotting, curves, levels, } \\
\text { saturation, contrast, and cropping are acceptable. By submitting entries, photographers acknowledge that } \\
\text { manipulation altering the material content has not been done. }\end{array}$ \\
\hline PPY & Any adjustments to any files submitted must be limited to those replicating conventional darkroom \\
\hline ESSO* & $\begin{array}{l}\text { téc serão considerados os trabalhos fotográficos que contenham elementos de informação jornalistica. Não } \\
\text { serão colocados em julgamento ensaios fotográficos, trabalhos de importância meramente técnica ou } \\
\text { artística. }\end{array}$ \\
\hline $\begin{array}{l}\text { HPA } \\
\text { ATLANT }\end{array}$ & $\begin{array}{l}\text { Only the necessary retouching which does not alter the original appearance of the photo is allowed } \\
\text { Only basic color correction and cropping are allowed to maintain the integrity and ethical standards of the }\end{array}$ \\
\hline & $\begin{array}{l}\text { industry. } \\
\text { Any types of distortion of the truth or excessive artistic effects are not allowed. }\end{array}$ \\
\hline HEARST & $\begin{array}{l}\text { The content may not be digitally altered significantly beyond standard optimization as in cropping, } \\
\text { reasonable adjustments to exposure, color and contrast, etc. It is not permissible to alter the basic reality of } \\
\text { a photograph. }\end{array}$ \\
\hline $\begin{array}{l}\text { DAYS JAPAN } \\
\text { CANTA* }\end{array}$ & $\begin{array}{l}\text { No retouching, compositing or other alterations (except for dodging, burning in, and cropping) is are allowed. } \\
\text { As fotos não poderão ser manipuladas digitalmente. }\end{array}$ \\
\hline & As fotografias não poderão ser manipuladas digitalmente. \\
\hline OASI & $\begin{array}{l}\text { All works must depict an accurate reflection of the subject and the scene just as they appeared to the author } \\
\text { be disqualified. }\end{array}$ \\
\hline $\begin{array}{l}\text { WPP } \\
\text { ETANOL* }\end{array}$ & $\begin{array}{l}\text { Only retouching which conforms to currently accepted standards in the industry is allowed. } \\
\text { A fotografia não poderá ser objeto de qualquer tipo de montagem, retoque ou recurso instrumental de } \\
\text { computacão. }\end{array}$ \\
\hline MPP & $\begin{array}{l}\text { Photographs in the sections for MACRO, NATURE and LIVE ACTION must be single capture with no retouching } \\
\text { that affects the authenticity of the photograph. The images must have been observed, but not fabricated in } \\
\text { any way by the photographer. }\end{array}$ \\
\hline NORTH EAST & $\begin{array}{l}\text { Please do not digitally enhance or alter photographs beyond the basics needed to achieve realistic colour } \\
\text { balance, contrast and sharpness. }\end{array}$ \\
\hline WILDLIFE & $\begin{array}{l}\text { The image should be a faithful representation of the original scene. Localised adjustments should be used } \\
\text { appropriately. }\end{array}$ \\
\hline LEICA & $\begin{array}{l}\text { the photos I am entering are neither photomontage nor have been manipulated or digitally altered in its } \\
\text { essence }\end{array}$ \\
\hline METEO & $\begin{array}{l}\text { essence } \\
\text { Se permitirán fotografías sin retocar, o sobre las que se hayan realizado ajustes (...) que no impliquen un } \\
\text { alejamiento excesivo de la imagen respecto a fotografía original. }\end{array}$ \\
\hline POYLatam & $\begin{array}{l}\text { As imagens devem refletir as notícias e os temas que concernem à sociedade, sempre respeitando a } \\
\text { integridade da cena e das circunstâncias reais. Imagens arrumadas ou construídas pelo fotógrafo não honram } \\
\text { a essência da fotografia documental. }\end{array}$ \\
\hline BWPA & This kind of work is comparable to what would be deemed as acceptable darkroom processing techniques. \\
\hline $\begin{array}{l}\text { DEFENDERS } \\
\text { IKPA }\end{array}$ & $\begin{array}{l}\text { The image should be a faithful representation of the original scene. } \\
\text { Photographs should accurately reflect the reality of the subject matter and the scene as it naturally appeared. } \\
\text { Any changes to the original photograph (adding or removing objects etc.) are unacceptable. Minor corrections }\end{array}$ \\
\hline KL & $\begin{array}{l}\text { (color corrections, cropping etc.) are acceptable. } \\
\text { Basic darkroom techniques are permissible in the Portrait Single category. Basic darkroom techniques e.g. } \\
\text { levels, curves, dodging, burning, minimal sharpening, colour correction are permissable. }\end{array}$ \\
\hline MORA & $\begin{array}{l}\text { Garantir que as imagens presentes ao concurso foram obtidas por meios fotográficos sem recurso } \\
\text { a manipulação, adição ou subtracção de elementos nas imagens, para além do normal tratamento, } \\
\text { enquadramento, reeguilíbrio de cor, densidade e contraste. }\end{array}$ \\
\hline EURONAT & $\begin{array}{l}\text { no subsequent modification of a picture or its content is permitted. We allow the standard picture-editing } \\
\text { processes applied to the picture as a whole (e.g. tonal value, contrast, brightness, colour, saturation, white } \\
\text { balance) }\end{array}$ \\
\hline DOCGRANT* & $\begin{array}{l}\text { All documentary images must be produced in actual occurrence and may NOT employ partial reenactment. } \\
\text { The emphasis must always remain on fact, not fiction. }\end{array}$ \\
\hline WALKLEY & $\begin{array}{l}\text { No cloning, montaging or digital manipulation other than cropping, 'digital spotting', burning and dodging is } \\
\text { permitted. }\end{array}$ \\
\hline CONSIGO* & $\begin{array}{l}\text { A Categoria Fotojornalismo levará em conta as imagens realizadas sem a interferência de qualquer tipo de } \\
\text { produção prévia, oriunda única e exclusivamente do olhar atento do fotógrafo que transmita conteúdo e } \\
\text { informação jornalística. }\end{array}$ \\
\hline MELVITA & It is very important that Entrants do not transform the nature of proposed images and files, although the \\
\hline $\begin{array}{l}\text { NATURAL } \\
\text { NATURE'S }\end{array}$ & technical op \\
\hline EOLO & $\begin{array}{l}\text { No se aceptarán fotografías en las que se haya aplicado fotomontaje y sí se aceptarán con ajustes de niveles } \\
\text { (exposición, contraste, saturación, etc.). }\end{array}$ \\
\hline $\begin{array}{l}\text { FOTOCAM* } \\
\text { MASKE }\end{array}$ & $\begin{array}{l}\text { que las mismas no han sido manipuladas ni modificadas alterando la realidad de la imagen captada. } \\
\text { Se permitirán manipulaciones digitales mínimas como corrección a la exposición, color o blanco y negro, }\end{array}$ \\
\hline CITIES* & $\begin{array}{l}\text { reescalar o reencuadre, pero nada que haga perc } \\
\text { La organización, en cualquier caso, podrá rechaz }\end{array}$ \\
\hline SHOOT & $\begin{array}{l}\text { remuestreada, retocada con programas informáticos para alterar su calid. } \\
\text { No se permiten alteraciones ni manipulaciones de la imagen o parte/s de esta, que impliquen que la fotografía } \\
\text { resultante pase a reflejar una realidad distinta a la fotografiada. En el procesado de las imágenes se admitirán } \\
\text { los ajustes propios del revelado digital: ajustes de luminosidad, saturación, niveles-contraste, temperatura de } \\
\text { color y enfoque y limpieza de partículas de suciedad. }\end{array}$ \\
\hline $\begin{array}{l}\text { DEL MAR* } \\
\text { YELMO* }\end{array}$ & $\begin{array}{l}\text { No se aceptan fotografías con modificaciones, donde se inserten o sustraigan elementos de la imagen original. } \\
\text { Se admitirán los retoques normales dentro de la revelación fotográfica pero NO se admitirán fotomontajes, } \\
\text { fotografías coloreadas, etc. }\end{array}$ \\
\hline $\mathrm{RIO}+20^{*}$ & $\begin{array}{l}\text { Las fotografias deben ser originales e inéditas, no alteradas ni manipuladas excepto por los ajustes de recorte } \\
\text { y optimización estándar que puede realizar el autor. }\end{array}$ \\
\hline ASFERICO & acceptable if limited to minor cleaning work, levels, curves, colour, saturation and \\
\hline CLARÍN* & $\begin{array}{l}\text { contrast work. The faithful representation of what you saw at the time of the shot must be maintained. } \\
\text { Las fotos no podrán ser intervenidas o manipuladas por ninguna técnica. Tampoco se aceptará ningún tipo } \\
\text { de montaje. }\end{array}$ \\
\hline CNPq* & $\begin{array}{l}\text { nontaje. } \\
\text { o aceitas imagens com retoques artísticos apenas nas Categorias 2, } 5 \text { e } 6 \text {. Na categoria } 4 \text { serão aceitas } \\
\text { tagens e imagens de longa exposição. }\end{array}$ \\
\hline LUIS & $\begin{array}{l}\text { the digital image can be altered using darkroom techniques. No other change to the original digital image } \\
\text { will be allowed. }\end{array}$ \\
\hline $\begin{array}{l}\text { ATLÂNTICA* } \\
\text { BELARUS }\end{array}$ & $\begin{array}{l}\text { será válida. a inscrição de fotografias manipuladas. } \\
\text { imal image modification is permited - technical retouching, contrast correction, cropping }\end{array}$ \\
\hline
\end{tabular}

* These contests are not in Table 1

Data analysis 
In this table, we highlight normative phrases within the regulations of competitions to evaluate whether this information clarifies the limits with regard to the use of editing software for experts who wish to submit their work. It is not an exercise in Linguistic Analysis or Discourse Analysis, but rather a detailed examination of certain generalities found in some of the regulations.

From the beginning, we find that most contests do not have strict rules but rather make general comments. They do not clearly specify the extent to which the use of certain procedures is considered manipulation rather than simple editorial treatment.

"Everyday corrections", "minor digital enhancement", "corrective functions", "basic processing", "using darkroom techniques", "only the necessary retouching", "aside from basic changes", "not be digitally altered significantly", "standard optimization", "beyond the needed basics", "beyond normal treatment", "minor digital manipulations", "adjustments of digital photos", "normal improvements", "standard optimization", "technical retouching": these types of expression permeate the regulations of contests without, obviously, clarifying very much.

Considering that we are dealing with a process in which postproduction intervention is inherent to its construction, how can we cope with such generic phrasings as "minimum enhancement", "routine fixes", "basic processing" and "using darkroom techniques"? What is meant by "do not change [a photo] substantially"? Many of the digital editing techniques have been used within photography for a long time. Photos have been manipulated since the beginning, so manipulation is not a privilege of the digital era. In dark rooms, employed techniques ranged from simple reframing to the implementation of sophisticated control masks. It is difficult for an expert by himself to determine what should be the maximum limit of touch-ups or a necessary basic improvements when it comes to adapting a photograph to what was originally perceived by the eye of the photographer.

Ansel Adams, in an interview given to David Sheff, said that what he did not see with his eyes he saw with his mind. This is what he referred to as "his view". According to this famous documental photographer, "I want a picture to reflect not only the forms but what I had seen and felt at the moment of exposure"18.

Those laconic phrasings, meant to ethically guide the behavior of photographers, actually leave gaps that can result in 
disqualifications and generate controversy through the mere fact that they are open to numerous interpretations.

When we find terms such as "standard optimization", "basic processing" or "ethical norms of the industry" in guidelines, we are led to believe that the organizers of some contests presuppose unanimity in the field regarding the terms "standard" and "basic" adjustment. Ambiguity is also present in the use of "etc.". For example: "photographs in which photo collages were applied will not be accepted, but photos with some level corrections (exposure, contrast, saturation, etc.) are allowed"; and "The content may not be digitally altered significantly beyond standard optimization as in cropping, reasonable adjustments to exposure, color and contrast, etc.". The term "etc." gives the impression that there is, in fact, uniform thinking in the field regarding ethical norms for digital photo editing. How should this be interpreted? Where does this alleged consensus come from? The term et cetera means "and so forth" and "and the others"; however, where can these other corrections that the rules are referring to be found?

Some contests are more explicit in their rules, especially when they clearly state that "photographs may not be manipulated or digitally altered". However, even similar categorical warnings are often accompanied by a supplementary note explaining that "basic modifications" are allowed. It might not be obvious to the professional what such basic modifications entail because what is meant by manipulation it is not really defined.

The terminology relating a photograph to the captured reality can be even more difficult to interpret and invite more disagreement. This is the case in the following examples: "Photographs should accurately reflect the reality of the subject matter", "altering the reality captured by the image", "do not distort reality", "which reflects a distinct reality than the one registered in the picture", or even, "preserve the authenticity of the image" and "The image should be a faithful representation of the original scene".

We have no intention of addressing the issue of the relationship between photography and reality in this article. We know that this association has been the subject of countless discussions, in sociology, aesthetics, philosophy and so forth, since the appearance of the photograph. The idea of photography as a faithful reproduction of the real world has been, for the past 40 years, gradually deconstructed (ROUILLÉ, 2009). Currently, the concept is mostly associated with the idea of photography as an artifice: the construction of a coded, 
subjective existence. A photo represents reality, but it is achieved through a process with many individual mechanisms preventing blind trust in its inevitable attachment to reality.

Top sum up, what we conclude from Table $\mathbf{2}$ is the need to clearly make the permissions and interdictions in contests statutes explicit. These rules are made based on the existence of a consensus in the field, which is currently ambiguous and subjective. Misconceptions and controversies are the actual result and will not help to distinguish between manipulation and "everyday corrections".

\section{FINAL REMARKS}

The initial proposal of this article was to verify whether the rules of contests for informational photos could provide strong guidelines that would define them as key institutions for norm-building in the field. To accomplish this, they would have to set clear limits to distinguish content manipulation from simple technical image adjustments.

Sixty-six contests were evaluated; of these, only 38 provided instructions in their rules regarding photograph editing procedures. The remaining contests made only vague comments, which we consider too generic to safely define guiding parameters because they are susceptible to subjective interpretations of what constitutes a drastic alteration in an image.

We were astonished by the fact that some international competitions simply do not mention the subject of photographic manipulation. We would expect these events to be important institutions for the experts to deliberate on issues related to informational photography ${ }^{19}$.

However, using the contests that list acceptable procedures when handling images in their regulations, we were able to identify some parameters as normative/deontological standards. In Table 1, a number of techniques are listed as acceptable by a large part of the competitions, although the degree to which these tools can be used is not specified; thus, caution and good sense are demanded. These techniques are cropping, sharpening, dodging, burning and corrections in contrast, brightness and color. In 2009, for example, photographer Klavs Bo Christensen was disqualified from the finals of the Picture of The Year in Denmark ${ }^{20}$ contest because the judges considered his color pictures to have been excessively dodged and burned. The photographer 
was excluded despite the controversy it generated because these procedures were allowed, but no limits for their use were specified.

Noteworthy in this paper was the requirement imposed on photographers by some contests ( $55 \%$ of the events) of presenting the RAW file in case it was demanded. Supposedly, the RAW file could be useful for the judges' evaluation if compared with the photo submitted to the contest. Nonetheless, RAW files have this name by virtue of being a "raw" prognostic of the image that will be generated. They carry only the information captured by the camera sensor, and provide a small file in JPEG (with alterations made by the image processing chips of the camera in relation to contrast, noise reduction, brightness, saturation, dynamic range, white balance and sharpness). This file obviously does not represent the final result and cannot cope with its entire dynamic spectrum. Furthermore, it is usually recommended that professional photographers overexpose the RAW file to obtain greater tonal latitude after using editing software, such as Adobe's Camera Raw. Therefore, based on what parameters can the RAW file (a draft of the photo) be compared to the final result?

Table 1 also notes some editing techniques that were banned by all the contests that mentioned them. Removing/adding, cloning and masks were considered to entail content manipulation and are therefore forbidden. In these cases, the prohibition is clear and it is easy for photographers to refrain from using these procedures. With regard to the techniques of saturation and digital filtering, although some contests accept them, they should be avoided so that photographers avoid the possibility of a subsequent disqualification.

In Table 2, the lack of clarity and objectivity in the comments made on the norms of photo editing becomes evident. Much of the terminology seems to spring from the assumption that certain "minimum levels", "basic processing" and "standard optimizations" are well known and have achieved consensus. This is not the case in our opinion. Our argument is sustained by the large number of cases in which famous experts are accused of misusing photography editing tools.

This paper did not intend to develop a set of norms of conduct, but only to note some possible consensus-forming tendencies (and mark more pronounced dissents) in photography contests. This was made possible through the analysis of a group of competitions that were taken as quality-identifier entities and therefore institutions able to build norms and standards of ethical-deontological behavior for the experts in this field. It is obvious that inaccuracy still permeates the ethical-deontological 
procedures in light of the new challenges brought about by the application of digital technologies in the production of photographic images. We believe that the conducted survey can bring some transparency with regard to the current scenario in (trans)formation.

\section{NOTES}

1 According to Lorenzo Vilches, "The genres are a way of communication established culturally, recognizable within certain social communities. As such, the genres are an arrangement of rules (technical-stylistics) to which photographs refer to accomplish their communicative and/ or connotative objectives." (VILCHES, 1987).

2 Source: Globo.com. In: http://www.techtudo.com.br/noticias/ noticia/2013/02/premio-de-fotografia-e-revogado-pelo-usoexagerado-do-photoshop.html. Consulted in: March, 2013.

3 "In two of the pictures, I used darkening techniques that photographers throughout the profession have used for decades, and continue to use at many reputable newspapers today. Unfortunately, the rules for how much a background can be darkened in order to improve a picture's visual impact have never been clear" (SCHNEIDER, Patrick apud BOORAEM, 2003).

4 Source: "In defense of photographer Patrick Schneider". Available at: http://www.zonezero.com/editorial/octubre03/october.html . Consulted in: February, 2013.

5 Source: Norman Blog. In: http://harryfisch.blogspot.com.es/2013/01/ national-geographic-how-i-won-and-lost.html. Accessed in: February, 2013.

6 Available at: http://www.bbc.co.uk/portuguese/ noticias/2012/11/121105_photoshop.shtml Consulted in: January, 2013.

7 Source: Peta Pixel. In: http://www.petapixel.com/2010/03/03/ world-press-photo-disqualifies-winner/ Consulted in: January, 2013.

8 PCN - Photography Competitions Network. In: http://www. photographycompetitions.net/ Consulted in: September, 2012.

9 FLINPO - Fotografia em Língua Portuguesa. In: http://www.flinpo.net/ Desafios/concursos.php Consulted in: September, 2012. 
MANIPULATION, PROFESSIONAL PRACTICES AND DEONTOLOGY IN INFORMATIONAL PHOTOGRAPHY

10 Photography Competitions Um Olhar Sobre a Cantareira; FECAM award for photography.

11 Prêmio Top Etanol de Fotografia (Top Ethanol Photography Award).

12 Naturaleza de Agenda Del Mar photo contest.

13 Leica Oskar Barnack Award.

14 All the contests listed and analyzed in this paper are quoted at the end of the essay, in our bibliography.

15 Sources: FotoLab Glossary. In: http://www.fotolab.com.br/glossario/, DPreview Glossary. In: http://www.dpreview.com/glossary Consulted in: March, 2013 and BOORAEM (2003).

16 HDR is a technique that uses many photos of the same scene, usually taken successively with a tripod or multiplied by editing software. The pictures, which are taken with different levels of exposure, i.e., luminosity, ranging from underexposed to overexposed, are then combined by the camera or a software program. The intention of HDR imaging is to generate a single image that captures a great dynamic range, from deep shadows to direct sunlight.

17 Available at: http://www.washingtonpost.com/blogs/ask-the-post/post/ critique-the-posts-front-page-january-13/2012/01/04/gIQABHJcwP_ blog.html Consulted in: June, 2013.

18 Available at: http://davidsheff.com/article/ansel-adams/ Consulted in: January, 2013.

19 Among them, we can find the Prêmio Latino Americano de Fotografía (Latin American Award of Photography), which has an exclusive category for photojournalism; the award of The Alexia Foundation, also dedicated to photojournalism; the Documentary Still Photography/Reportage Award/ Grant, sponsored by a foundation (e.g. FSA) that intends to bring back the aura from the documentaries of the past, according to its objectives; the New Holland Award in photojournalism; and the European Professional Photographer of the Year Awards, which explicitly aims to promote professional photographers and raise the level of expertise in the field. All of the other contests referenced in this part of the paper are cited in our bibliography but do not appear in any of the tables because they do not mention the issue of photographic editing and manipulation in their rules. 
20 Available at: http://buildingsandfood.com/howto-not-win-thepicture-of-the-year-in-denmark Consulted in: November, 2012.

\section{REFERENCES}

ALCÁNTARA HERNÁNDEZ, Ma Ángeles; DOMíNGUEZ DELGADO, Rubén. La responsabilidad ética del documentalista de los medios de comunicación. Actas del I Congreso Internacional de Ética en la Comunicación, Facultad de Comunicación, Universidad de Sevilla, March 2011. Available at: http://monitorando.files.wordpress.com/2011/04/ libro-actas-congreso-etica-comunicacion.pdf

BOORAEM, Melissa Marie. Practices of Manipulation by Professional Photojournalists, ABJ, The University of Georgia, 2003.

BAEZA, Pepe. Por una función crítica de la fotografía de prensa. Barcelona : Editorial Gustavo Gili, 2001.

IRBY, Kenneth (2003). A photojournalistic confession. Poyter Online. Available at: < http://www.poynter.org/uncategorized/14840/aphotojournalistic-confession/> Accessed on January 30, 2013.

FONTCUBERTA, Joan. EI Beso de Judas Fotografia y verdad. Barcelona: Editorial Gustavo Gili S.A, 1998.

FRANQUET DOS SANTOS, Miguel. Códigos de ética y fotografía de prensa. Actas del I Congreso Internacional de Ética en la Comunicación, Facultad de Comunicación, Universidad de Sevilla, março 2011 . Available at: http://monitorando.files.wordpress.com/2011/04/libro-actascongreso-etica-comunicacion.pdf

LISTER, Martin. La imagen fotográfica en la cultura digital. Barcelona: Ediciones Paidós, 1997.

LONG, John (1999). Ethics in the Age of Digital Photography. NPPA. Available at: http://www.nppa.org/professional development/selftraining resources/eadp report/eadptxt.html

MARTINEZ CUSINOU, Pablo. Dilemas éticos y discursividad en el fotoperiodismo. In: Actas del I Congreso Internacional de Ética en la Comunicación, Facultad de Comunicación, Universidad de Sevilla, março 2011. Available at: http://monitorando.files.wordpress.com/2011/04/ libro-actas-congreso-etica-comunicacion.pdf

MITCHELL, William J. The Reconfigured Eye: Visual Truth in the PostPhotographic Era. London, England: The MIT Press, 1992.

MOUTINHO, Sara. Manipulação de imagens fotográficas Jornalísticas. Falsificação da realidade visível. In: PINTO, Manuel; SOUSA, Helena (org.). Casos em que o jornalismo foi notícia. Porto: Campo das Letras Ed., 2007. 
NEWTON, Julianne Hickerson. The Burden of Visual Truth: the role of photojournalism in Mediating Reality. London: Lawrence Erlbaum Associates, Inc., 2001.

ORIEZ, Richard J. (2009). Do Readers Believe What They See? Reader Acceptance Of Image Manipulation. A Thesis presented to the Faculty of the Journalism School at the University of Missouri-Columbia. Available at: https://mospace.umsystem.edu/xmlui/bitstream/ handle/10355/6551/research.pdf?sequence $=3$

PAIM, Isis; NEHMY, Rosa Maria Quadro; GUIMARÃES, César Geraldo. Problematização do conceito "qualidade" da informação. Perspectivas em Ciência da Informação, Belo Horizonte, v. 1, n. 1, p. 111-119, 1996.

SOUSA, Jorge Pedro (1998). A tolerância dos fotojornalistas portugueses à alteração digital de fotografias jornalísticas. Covilhã - BOCC ( Biblioteca On-line de Ciências da Comunicação) Universidade da Beira Interior. Available at: http://www.bocc.ubi.pt/ pag/texto.php?html2=sousa-pedro-jorge-Alteracao-Fotografias.html

SUÁREZ VILLEGAS, Juan Carlos (Org). La ética de la Comunicación a comienzo del siglo XXI. Actas del I Congreso Internacional de Ética en la Comunicación, Facultad de Comunicación, Universidad de Sevilla, March 2011. Available at: http://monitorando.files.wordpress.com/2011/04/ libro-actas-congreso-etica-comunicacion.pdf

VICHES, Lorenzo. Teoria da la imagen Periodística. Barcelona: Paidós Comunicación, 1987.

WHEELER, Thomas H. Phototruth or photofiction? Ethics and Media Imagery in the Digital Age. Mahwah, New Jersey: Lawrence Erlbaum Associates, Inc, 2002. SOJO, Carlos Abreu. Los géneros Periodísticos Fotográficos. Barcelona: Editorial CIMS, 1998.

\section{Contests Analyzed*:}

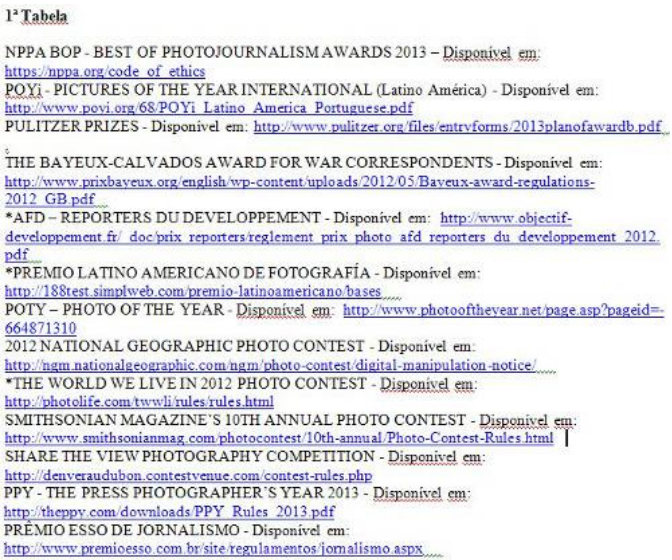


$2^{2}$ Tabela

HPA - THE HUMANITY PHOTO AWARDS 2013 - Disponivel em:

http: WWW hpa. org. cn en Constitution. aspX

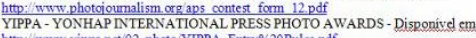

http: : www vippa net 02 pla1

THE HEARST JOURNALISM AWARD PROGRAM-Disponivel em:

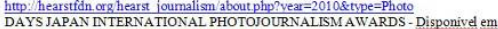

http: www. daysiapan net e award index htoml

"THE ALEXIA FOUNDATION - Disponivel em: hrto:/www alexiafoundation org grants professio

12.29 content $1905 \mathrm{htm}$. htto:/ wwiv recanta ore br regulamento concurso fotografia htoml

LCAM- PREMOFECAM DE FOTOGRAFA - Disponivel em

http: Www fecam. org, br agenda index php? cod evento=603 Disponivel em: hitp:/ www. worldphoto.org competitions/sony-world-photography-awards-2013-prof competition

TH ANNUAL CONSERVATION PHOTOGRAPHY CONTEST - Disponivel em BELARUS PRESS PHOTO - 2013 - Disponivel em: httpo/ pressphoto, bv ?page id=345\&lang=en OASIS PHOTO CONTEST - Disponivel em: htttp:/ www. oasisphotocontest com regolamento. asp? a

WPP- WORLD PRESS PHOTO CONTEST - Disponivel em:
https:/wppweb1. submit worlduressphoto org sites default files documents Entrv\% 620 Rules $\% 20$ and\% on\%202013\%20-\%20English 0.pdf

\section{$3^{2}$ Tabela}

MPP - MACQUARIE PHOTOGRAPHY PRIZE - Disponivel em http:/australianartsales.com.au/MacquariePrize/Macquariephotograhyprize html NORTH EAST WILDLIFE PHOTOGRAPHY COMPETITION 2013 - Disponivel http:/www nwt org ulk sites/default files files How $\% 20$ to $\% 20$ enter $\% 20$ photograph WILDLIFE PHOTOGRAPHER OF THE YEAR - Disponivel em: http:/www nhm us/whats-on/temporary-exhibitions/wpy/enter/guidelines.jsp *MAGNUN EXPRESSION AWARD - Disponivel em.

http:/expression magnumphotos.com/librarv/terms conditions.pdf

LEICA OSKAR BARNACK AWARD - Disponivel em: http:/ www leica-oskar-b award.com/\#/en/applying/contest-rules

METEO - CONCURSO DE FOTOGRAFIA METEOREPORTAJE'2012 - Disponí http:/www ame-web.org meteoreportaje 2012 basesmeteoreportaje2012.pdf POY LATAM - PICTURES OF THE YEAR LATAM 2013 - Disponivel em: http:/www nuestramirada.org page convocatoria portugues 2013 BWPA - BRITISH WILDLIFE PHOTOGRAPHY AWARDS - Disponivel em: http:/bwpawards.org/c competition/submission-guidelines-and-how-to-enter DEFENDERS OF WILDLIFE'S 4TH ANNUAL PHOTO CONTEST - Disponivel http:/ www defenders.org/defenders-wildlifes-4th-annual-photo-contest \#rules IKPA - INTERNATIONAL KONTINENT PHOTOGRAPHY AWARDS 2013 - D

http:/kontinentawards.com/categories/ http:/www klphotoawards.comirules.htm

4.'Tabela

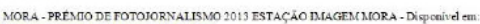

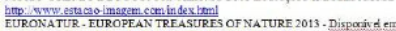

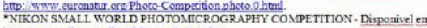

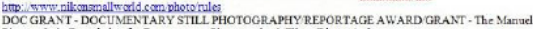

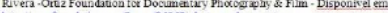

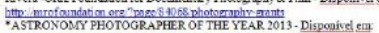

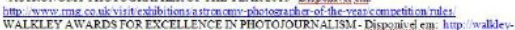

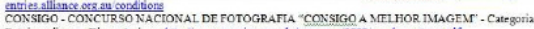

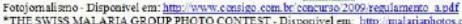

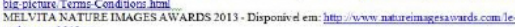

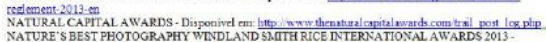

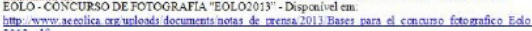

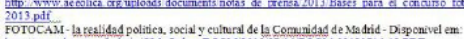

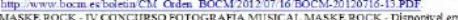

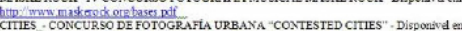

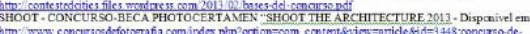

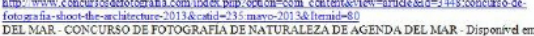
"REVELA II PRETIO NTERRNACTONAL DE FOTOGRAFLA A 105 TITULARES DE LOS DERECHOS

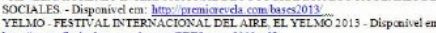

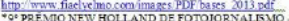

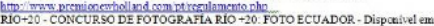

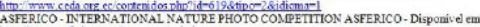

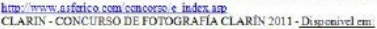

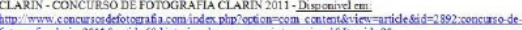

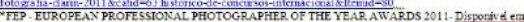

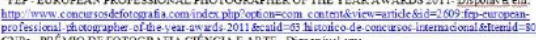
CNFG-PRÉRIO DE FOTOGRAFA CIÉNCIAE EARTE- Disponivel em:

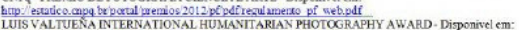

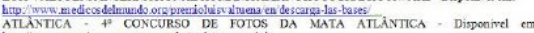

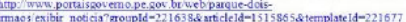


* These contests, although analyzed by us, were not included in the tables, as there is no mention in their rules of the issue of editing or photo manipulation.

** All contests in our universe of analysis were consulted between September 2012 and March 2013.

Paulo Munhoz is a Professional Photojournalist and University Lecturer in Photography (Universidade Federal da Bahia and Faculdade Social da Bahia). B.A.in Industrial Design (Pontifícia Universidade Católica do Paraná ) and Master in Communication (Universidade Federal da Bahia). Associated researcher at Gjol - UFBa (Online Journalism Research Group), since 2003, and Ph.D. candidate in the Postgraduate Program in Communication and Contemporary Culture (Universidade Federal da Bahia). E-mail: paulocvmunhoz@gmail.com 